This is the post-print version of the following article: Jones, Glen A. (2009). Sectors, Institutional Types, and the Challenges of Shifting Categories: A Canadian Commentary. Higher Education Quarterly 63(4), 371-383. The final form is published at: http://onlinelibrary.wiley.com/doi/10.1111/j.1468-2273.2009.00439.x/abstract

\title{
SECTORS, INSTITUTIONAL TYPES, AND THE CHALLENGES OF SHIFTING CATEGORIES: A CANADIAN COMMENTARY
}

\author{
Glen A. Jones \\ Ontario Institute for Studies in Education, University of Toronto
}

\begin{abstract}
While the English system makes a relatively clear distinction between higher education and further education, the Canadian approach has been to use higher education as a more inclusive term and to categorize sectors on the basis of institutional type. Higher education policy is decentralized and the responsibility of provinces that have made quite different decisions about institutional categories and system structures. The boundaries between institutional types have been blurring and there has been a growth in articulation, collaboration and hybrid relationships between institutions and sectors.
\end{abstract}

The objective of this paper is to offer a Canadian commentary on the role institutions that combine further and higher education in England, as analysed by Gareth Parry in this volume. This will be accomplished by outlining some important key differences between the English and Canadian experience, especially in terms of defining higher education, the role of further education programming within Canadian universities, the blurring of the boundaries between the university and college sectors in some Canadian provinces, and the growth of articulation, collaboration and hybrid relationships between institutions.

\section{Defining higher education in Canada}

In the contemporary English system there is a relatively clear distinction between higher education, defined as educational programming for postgraduate and undergraduate education , and further education, which is synonymous with other kinds of post-compulsory education and training, mostly at levels below higher education. In the Canadian context versions of both types of activity are associated with institutions that are classified as part of a more broadly defined higher education (or postsecondary education) sector. Historically, Canadian higher education has been characterized as having two institutional types, universities, which have been traditionally defined by their authority to grant degrees and some other institutional characteristics, and community colleges.

These definitional differences underscore the different ways in which 'sectors' are understood within England and Canada. In the English system the sectors are defined by types and levels of educational programming. Each of the two categories of educational programming (further and higher education) is regulated and funded by a distinct council. Institutions in England which provide both sets of activity are sometimes described as 'dual sector' or 'mixed economy' establishments. They are publicly funded directly or indirectly by both councils. In most cases 
these dual sector institutions are largely focusing on educational programming in one sector, but are engaged in small pockets of activity in the other. In a small number of institutions the level of activity in both sectors is substantial.

Canada is a federal state comprised of ten provinces and three territories. The Canadian constitution assigns responsibility for education to the provinces, and the provinces have strongly resisted direct federal government interference in educational policy issues at any level, from kindergarten to graduate education. There is no national ministry of higher education and no national higher education policy or policy framework (Jones, 1997; 2006). Higher education policy is decentralized. Canadian higher education can therefore be defined as the sum of activities taking place within thirteen provincial/territorial systems of higher education, and, as described in more detail below, these systems have evolved to include quite different institutional types, regulatory structures, and funding mechanisms.

In Canada, the term 'higher education' is viewed as synonymous with postsecondary or tertiary education and generally refers to the sum total of activities associated with institutions that focus on the provision of education programming beyond the level of the secondary school. In the Canadian context, the term 'sectors' has been used to refer to groupings of institutional types within these broadly defined provincial systems of higher education. Most provincial governments have assigned responsibility for all of higher education to a single government ministry, and this ministry has developed distinct regulations and funding mechanisms for different institutional sectors. Historically, these institutional types have been categorized as universities and community colleges (see Jones, 1997).

There are both private and public institutions within Canadian higher education, though the vast majority of students attend institutions that are considered 'public' in that these institutions receive government operating grants. Private (non-government funded) institutions include religious colleges that offer degrees in theology, for-profit career colleges, and a small number of universities. Public institutions receive government grants and, with the exception of Quebec colleges, charge tuition fees. There are approximately 60 publicly funded universities and 180 community colleges, though one can find quite different institutional counts depending on the information source and classification system (Jones, 2006). Since Canada has two official languages (English and French), institutions can also be categorized by language of instruction; the vast majority of institutions offer programs in only one language (English or French), though a small number of institutions offer programs in both official languages.

In 2004/05 there were approximately 785,900 undergraduate students enrolled in Canadian universities (approximately 631,900 full-time) and approximately 514,000 full-time students enrolled in public colleges and institutes, though it is important to note that the latter includes students enrolled in certificate and diploma programs as well as university transfer programs (Canada Education Statistics Council, 2007). The role and structure of the community college sector varies by province but, until recently, the sector was at least partly defined by the fact that these institutions did not have the authority to grant degrees.

Understanding the difference in how the term 'higher education' is defined becomes important in comparing the English and Canadian experiences because in Canada the university and college sectors have both been regarded as components of provincial higher education systems. There may be different funding mechanisms by sector, but both sectors function under the regulatory eye of the same provincial ministry and are considered component parts of a single provincial higher education system. 


\section{Universities and 'further education'}

Universities, as an institutional type, have largely been defined as comprehensive, secular, autonomous institutions that have the legal authority to grant degrees. However, universities also frequently offer a range of sub-degree programs and continuing education activities that might well be defined as 'further education' under the English system.

There were no universities west of Ontario when the Dominion of Canada was created in 1867, and the new universities that emerged in each of the four new western provinces (Manitoba, Saskatchewan, Alberta, and British Columbia) assumed a special role as 'provincial' universities. The original notion was that there would be a single, secular provincial university in each jurisdiction that would assume responsibility for addressing the higher education needs of each province. The new provincial universities also represented a mechanism for avoiding the bitter competition for public resources between different denominational colleges that was taking place in Ontario and Nova Scotia during this period. Not surprisingly, given their emergence in the late nineteenth and early twentieth century and their province-wide mandates, these institutions were heavily influenced by the American state university model, especially the University of Wisconsin, and they moved quickly to develop programs in relevant applied fields, such as agriculture, in addition to traditional programs in the arts, sciences, and professions. These universities also offered short-cycle programs from departments of extension or continuing education with the understanding that these institutions had a role to play in the broader social, cultural and economic development of the jurisdiction.

Over time, most Canadian universities developed continuing education units or extension initiatives. Much of this activity involves the provision of general interest courses that do not lead to any form of recognized credential, but many universities also offer vocational education certificate and diploma programs. For example, a number of universities (especially in western Canada) have a long history of offering agricultural diploma programs, and many continuing education units offer certificate and diploma programs that are clearly vocationally oriented. Depending on local needs (and the market), university continuing education units often provide English as a Second Language (ESL) programs and other forms of adult upgrading programming. Unfortunately, there is no national enrolment data on university-based short-cycle vocational programming, but using the English definition, most Canadian universities offer at least a very modest level of further education programming. The continuing education units at most universities have a mandate to generate revenue (or at least be completely self-funding) and many vocational certificate and diploma programs have emerged as a function of institutional entrepreneurship. Most have open access admissions strategies, but charge fees at levels designed to generate profits for the institution.

\section{The evolution of the provincial college sectors}

While many universities offer versions of further education programming, the story of higher education sectors and institutional differentiation in Canada is largely tied to the development and evolution of community colleges. The initial post-war expansion of higher education in Canada was funded by direct federal government grants to universities, but by the 1960s the provinces were asserting their constitutional rights over education (now assumed to include higher education) and the federal government shifted from direct support to indirect funding through transfers to the provinces. The ten provincial governments now assumed the 
central role in planning and funding the expansion of postsecondary education, and this expansion process led to the creation of a new type of institution in each province that had a mandate to provide vocational education, and often involved integrating what had previously been separate, specialized vocational institutes.

While these new institutions were frequently called 'community colleges' there were tremendous differences in the role, mandate, and structure of these institutions by province, in part because the provinces made very different decisions about how to structure their expanding higher education systems (Dennison \& Gallagher, 1995; Jones, 1996). The province of Quebec restructured its entire educational system (from kindergarten to graduate school) as a component of a broader range of social reforms that became known as the 'Quiet Revolution', and the province created the Collège d'enseignement général et professionnel (CEGEP or College of General and Vocational Education) to play an intermediary role between school and university as well as offer vocational programs. Students in Quebec complete secondary school at the end of grade 11 (usually at 17 years of age). Continuing students then attend a CEGEP and enrol in either a two-year pre-university program, or a vocational program (usually three years in length). These are regional, high access institutions that do not charge tuition fees.

Unlike Quebec, other provinces had or were moving towards adopting a twelve year public school system similar to the American model, but there continued to be major differences in curriculum by province. In Ontario, students could graduate at the end of grade 12, but university-bound students completed a thirteenth year of secondary school (until 2003 when the province moved entirely to a 12 grade curriculum). In other words, the Canadian educational system has been so decentralized that there have been (and continue to be) differences by province in the length of the secondary school curriculum.

The provinces of British Columbia and Alberta created community colleges that more closely resembled the American model in that the colleges offered two distinct types of postsecondary educational programs: students could attend a local community college to take the first two years of university credits; or they could enrol in a two-year career-oriented diploma program. Under this model, the community colleges became a mechanism for expanding access to the first two years of university degree programs as well as providing new opportunities for students to enrol in technical and vocational programs. Students who successfully completed two years of specified university credit courses in the community colleges could transfer and be admitted into the third year of a degree program at a provincial university. In addition to community colleges, both provinces also created institutes of technology that would offer non-degree, career-focused, technical programs (See Dennison, 1997; Andrews, Holdaway \& Mowat, 1997).

The remaining provinces created institutions that focused on providing postsecondary technical/vocational programs, but these community colleges did not have a university transfer function. In most provinces these colleges offered trades and two-year technical/vocational diploma programs, while the new Ontario Colleges of Applied Arts and Technology offered programs of up to three years in length. In these provinces the colleges provided students with an alternative to university, but they did not provide students with an alternative route to a university degree, and issues of credit transfer and credential recognition were frequently raised as students attempted to move from one sector to the other (Jones, Skolnik \& Soren, 1998).

In terms of dual sector institutions, then, only three provinces created institutional types during this period that had an explicit mandate to offer programs linked to the university sector as well as further education programming. The Quebec CEGEPs became the required pathway to 
university and were designed to be a highly accessible, intermediary institution that would facilitate the transition from secondary school to university. The British Columbia and Alberta community colleges were designed to provide students who did not live close to a traditional university with local access to the first two years of university credits, in addition to offering career-focused diploma programs. Alberta and British Columbia also created provincial councils (the Alberta Council on Admissions and Transfer and the British Columbia Council on Admissions and Transfer) that facilitated the creation of explicit arrangements for credit recognition and transfer between institutions so that a student would know in advance how a course credit obtained at one institution would be treated by others within that jurisdiction. Detailed information on credit recognition arrangements between all institutions in each provinces are now available on-line through transfer guides maintained by these councils. For example, a student who takes a specific first year Art History course at the Alberta College of Art and Design can use the transfer guide to learn that the course will be recognized for full credit towards a degree program at the University of Alberta.

While at one point it might have been possible to argue that there were clear boundaries between the university and college sectors, these boundaries have become blurred in several provinces by government decisions to extend the authority to grant degrees to institutions that are not regarded as universities (Shanahan \& Jones, 2007). British Columbia provided limited degree-granting authority to the Emily Carr School of Art and Design (a specialized art school that would later become the Emily Carr University of Art and Design) and the British Columbia Institute of Technology (which offered apprenticeship programs and a range of business and technical diploma programs). British Columbia also transformed a number of its community colleges into 'university colleges', institutions that would later have the independent authority to offer degrees while retaining a strong mandate to offer trades and diploma programs in applied fields (Dennison, 1997; Fisher, Rubenson, Jones \& Shanahan, 2009), and, under the province's University Act of 2008, most of these institutions were repositioned and renamed as universities. These new regional universities are clearly dual (university and college) sector institutions with the authority to grant degrees while retaining a historic role in short-cycle vocational programming and apprenticeship training.

The province of Alberta initially expanded degree-granting authority by allowing colleges and institutes to award 'applied degrees', essentially a new credential involving three years of course work and one year of supervised work experience. The term 'applied degree' was used to signal the more applied, vocational emphasis of the curriculum, but also to appease the concerns of universities. Alberta's Postsecondary Learning Amendment Act of 2008 establishes six sectors of postsecondary institutions and expands the types of institutions that can offer 'baccalaureate' degrees (in addition to 'applied degrees') subject to a provincial review of new degree proposals. Each sector is described in terms of the types of credentials that they can award and their role in research. For example, only institutions in the 'Comprehensive Academic and Research Institutions' sector can award masters and doctoral degrees.

Ontario also passed legislation that allowed its Colleges of Applied Arts and Technology to offer degrees in applied areas subject to government approval based on advice from a new Postsecondary Education Quality Assessment Board which reviewed all new proposals (Laden, 2005). Unlike Alberta, the Ontario applied degrees have a four-year structure and rigour that more closely resembles traditional degree programs in the university sector (see Skolnik, 2005; Jones and Skolnik, 2009). It is also important to note that Ontario colleges also offer post-diploma programs that are aimed at students who already have a university degree or college diploma, for 
example a career-oriented one-year diploma in a field of applied social science that builds upon a liberal arts undergraduate degree.

One of the challenging issues associated with the expansion of degree-granting and the emergence of new universities concerns the role and funding of research. Canadian universities receive a provincial operating grant that supports the basic research, teaching and service functions of the institution, and then professors seek out support for the direct costs of research through competitive research grant mechanisms operating by federal research councils, or research contracts with industry, government, or private foundations. Generally speaking, provincial funding mechanisms have treated colleges as primarily teaching institutions and assumed that universities have a core research function. Historically, federal research grants have only been available to institutions within the university sector. Given that the university sector was largely defined on the basis of its ability to grant degrees, the shifting boundaries associated with the expansion of degree-granting also have ramifications for the role of these new degree-granting institutions and their faculty in research. The number of institutions eligible for research grants has expanded. Some colleges have advocated for special funding to support an 'applied research' function that would parallel their applied degree programming. Given the increasing importance placed on research and research grant funding in terms of institution status, international rankings and university revenues, even the very limited successes of these new entrants into the research community are creating an increased sense of competition and tension. As the established institutions stand around the modest research watering hole, the sudden emergence of younger, thirsty peers, however small, does little to create a mutually supportive environment.

In reviewing the history of higher and further education in England, Parry (2008) discusses the complexities, tensions, and ambiguities that have emerged as institutions navigate through two funding and regulatory regimes and enter into new forms of collaboration and cooperation involving both sectors. The recent history of system-level structural change in several Canadian provinces has involved at least a blurring of boundaries between sectors, and in some cases a complete redrawing of the borders, with considerable experimentation in the development of new institutional categories and credentials.

Increasing accessibility to higher education has been a major rationale underscoring most of these reforms. The creation of the community colleges in the 1960s was designed to increase accessibility by expanding the range and types of educational options available to students, and, in several provinces, expanding geographic accessibility by offering university transfer programs in underserviced regions. The colleges accomplished this objective. While a larger number of students attend universities, the colleges offer a range of important vocational programs that are frequently directly linked to the labour market, and they attract a larger share of students from lower socio-economic backgrounds than their university peers. Expanding degree granting status to the colleges and disrupting what had once been clear boundaries between institutional types have been strategies designed to increase accessibility to higher education in two ways. First, in some cases the ability to expand offerings has allowed institutions to ladder educational programming for existing students; students who might have completed two years of postsecondary education may now decide to complete a four year credential since the challenges of transitioning between institutional types for a degree no longer exists. Second, the expansion of degree granting is designed to increase access to degree programs by attracting students who want a degree but would not have attended a university.

\section{Articulation, collaboration and hybrid relationships}


Some institutes of higher education in England subcontract higher education program activities to institutes of further education, and this approach accounts for much of the higher education activity within the further education sector. The Canadian parallel has been the growth of articulation and collaborative arrangements between individual institutions in each sector.

There has been considerable interest in understanding how students move through the educational system in terms of transferring from one institution to another in the context of lifelong learning, and in understanding the barriers to student mobility and the factors that influence student choice (Andres, 1999; Lang, 2009). As already noted, most provinces created a community college sector that did not include an explicit university transfer function, and there has been an increasing interest in finding ways for graduates of the college sector to continue their education in the university sector and have some or all of their prior education recognized for credit towards degree programs. Decisions on credit recognition were in the hands of individual universities, and there were differences of opinion between institutions and between sectors in terms of the level of credit that should be awarded. Articulation between the sectors became a major policy issue (Jones, Skolnik \& Soren, 1998). In some provinces, such as Ontario, there continue to be quite serious concerns that systemic issues are preventing students from moving freely between the sectors (Jones and Skolnik, 2009).

While the issue is far from resolved, there has been a growth in formal articulation arrangements between institutions. Under these arrangements, a college and a university enter into an agreement concerning how the university will treat successful graduates of the college; the agreements frequently deal with the transition from a specific college diploma program into a related university degree program. Articulation arrangements provide students with a clearer sense of future possibilities, and colleges advertise the existence of these arrangements in their recruitment materials.

There has also been a growth in collaborative programs, especially in Ontario, where individual colleges and universities have worked together to create degree programs where some of the degree requirements are met within a college environment and some are met within a university environment. For example, many nursing students in Ontario are now enrolled in collaborative programs where some of the curriculum is the responsibility of a college (by college faculty using college facilities) and some of the curriculum is the responsibility of a university. These are not sub-contract or franchise arrangements, but rather collaborative degree programs where two legal entities have entered into an agreement to work together. They are not equal partners, however, since only the university, in this example, has the legal authority to grant the degree. Athabasca University in Alberta, which refers to itself as 'Canada's Open University' has numerous articulation arrangements with colleges throughout the country; these arrangements clearly describe how the college program will be recognized by Athabasca and the number of additional course credits that will be needed to complete a degree program.

Finally, there has been a growth in hybrid relationships. The University of Guelph and Humber Institute have jointly created Guelph at Humber, a joint facility that offers Guelph degree programs on the Humber campus. Seneca College in Toronto has a campus at York University. The Government of New Brunswick (2008) is proposing the creation of Institutes of Applied Learning and Training, corporate entities owned by a community college and university in each region, that will facilitate college-university linkages in the development of new program initiatives. There has been an increase in experimentation in hybrid relationships that may involve 
joint programming, and the sharing of facilities or resources to complement specialized articulation arrangements or collaborative activities.

Provincial governments have generally supported increased articulation and collaboration between sectors. These arrangements can increase accessibility to higher education, but perhaps more importantly they can increase access to higher levels of postsecondary education through the formal development of laddering arrangements so that the steps from one credential to the next become clearer.

\section{Concluding observations}

In Canada, as in England, the boundaries between what were once clearly differentiated sectors have blurred as institutions and governments attempt to address societal needs and increase access to further and higher education, especially to degree programs. However, there are significant differences in the way that these sectors have been defined in Canada and England, and the systems have evolved in quite different ways. Some of these differences are probably more related to Canada's highly decentralized approach to higher education policy; the absence of a strong federal or national presence in this policy area has been a factor in the rise of quite different provincial institutional types and system policies. What was once a clear binary structure in most Canadian provinces has now evolved into a far more complex system with multiple institutional types, contested boundaries, and complicated inter-institutional relationships (Marshall, 2009).

Recent events in several provinces serve to illustrate the complexity and magnitude of these changes. As noted above, legislation approved by the Government of Alberta in 2008 defines six sectors within that system of higher education and articulates the role and function of each sector. In the same year British Columbia transformed a network of university colleges into autonomous regional universities. The Government of New Brunswick (2008) has announced major reforms to its community college sector that will include the introduction of first and second year university transfer courses at selected campuses and mechanisms to facilitate further articulation arrangements with the province's universities. In 2009 the Government of Manitoba announced amendments to the Colleges Act that provide community colleges with the authority to grant baccalaureate degrees with an applied focus. Manitoba is now the fifth of Canada's ten provinces to provide some form of baccalaureate degree-granting authority to the community college sector.

In comparison with the Canadian situation, the boundaries between further and higher education in England seem somewhat clearer and more stable than the boundaries between institutional types in at least some Canadian provinces. Definitional differences may be key to understanding and comparing these systems: the further and higher education sectors in England seem to be structured as separate games (with dual sector institutions playing cards at two tables) while in the Canadian provinces one has a sense of multiple sectors playing the same game, though with different roles assigned to different players, and, sometimes, with great differences of opinion over rapidly changing rules.

\section{References}

Andres, L. (1999). Investigating Transfer: The Student's Perspective. Vancouver, B.C.: British Columbia Council on Admissions and Transfer. 
Andrews, M., Holdaway, E., \& Mowatt, G. (1997). Postsecondary education in Alberta since 1945. In G. A. Jones (Ed.), Higher education in Canada: Different systems, different perspectives. (pp. 59-94). New York: Garland Publishing.

Canada Education Statistics Council. (2007). Education Indicators in Canada: Report of the Pan-Canadian Education Indicators Program 2007. Toronto: Canada Education Statistics Council.

Dennison, J. D. (1997). Higher education in British Columbia, 1945-1995: Opportunity and diversity. In G. A. Jones (Ed.), Higher education in Canada: Different systems, different perspectives. (pp. 31-58). New York: Garland Publishing.

Dennison, J. D. \& Gallagher, P. (1995). Canada's community college systems: A study of diversity. Community College Journal of Research and Practice, 19(5), 381-394.

Fisher, D., Rubenson, K., Jones, G. \& Shanahan, T. (2009). The Political Economy of Post-Secondary Education: A Comparison of British Columbia, Ontario, and Quebec. Higher Education, 57: 549-566.

Jones, G. A. (1996). Diversity within a decentralized higher education system: The case of Canada. In V. L. Meek, L. Goedegebuure, O. Kivinen, and Ri. Rinne (Eds.), The Mockers and Mocked: Comparative Perspectives on Differentiation, Convergence and Diversity in Higher Education (pp. 79-94). Oxford: Pergamon.

Jones, G. A. (Ed.) (1997). Higher Education in Canada: Different Systems, Different Perspectives. New York: Garland Publishing.

Jones, G. A. (2001). Islands and Bridges: Lifelong Learning and Complex Systems of Higher Education in Canada. In D. Aspin, J. Chapman, M. Hatton, and Y. Sawano (Eds.), International Handbook of Lifelong Learning (Volume 2, pp. 545-560). Dordrecht, The Netherlands: Kluwer Academic Publishers.

Jones, G. A. (2004). Ontario Higher Education Reform, 1995-2003: From Modest Modifications to Policy Reform. Canadian Journal of Higher Education 34(3), 39-54.

Jones, G. A. (2006). Canada. In J. J. F. Forest and P. G. Altbach (Eds.), International Handbook of Higher Education (pp. 627-645). Dordrecht, The Netherlands: Springer.

Jones, G. A. \& Skolnik, M. L. (2009). Degrees of Opportunity: Broadening Student Access by Increasing Institutional Differentiation in Ontario Higher Education. Toronto: Higher Education Quality Council of Ontario.

Jones, G. A., Skolnik, M. L., \& Soren, B. (1998). Arrangements for Coordination Between University and College Sectors in Canadian Provinces: 1990-1996. Higher Education Policy, 11(1), 15-27. 
Laden, B. V. (2005). The New ABDs: Applied Baccalaureate Degrees in Ontario. In D. L. Floyd, M. L. Skolnik \& K. P. Walker (Eds.), The Community College Baccaluareate: Emerging Trends and Policy Issues (pp. 153-158). Sterling, VA: Stylus Publishing.

Lang, D. (2009). Articulation, Transfer, and Student Choice in a Binary Post-Secondary System. Higher Education, 57-355-371.

Manitoba. (2009, April 23). Manitoba Colleges Would Offer Baccalaureate Degrees Under Proposed Amendments. (News Release). Winnipeg: Government of Manitoba.

Marshall, D. (2008). Differentiation by Degrees: System Design and the Changing Undergraduate Environment in Canada. Canadian Journal of Higher Education, 38 (3), 1-20.

New Brunsick (2008). Be Inspired. Be Ready. Be Better. Action Plan to Transform Postsecondary Education in New Brunwick. Fredericton: New Brunswick.

Parry, G. (2008) Higher and further education: the significance of sectors for expansion, differentiation and participation in undergraduate education in England (mimeo).

Shanahan, T. \& Jones, G. A. (2007). Shifting Roles and Approaches: Government Coordination of Postsecondary Education in Canada from 1995 to 2006. Higher Education Research and Development, 26(1) 31-43.

Skolnik, M. L. (2005). The Community College Baccalaureate in Canada: Addressing Accessibility and Workforce Needs. In D. L. Floyd, M. L. Skolnik \& K. P. Walker (Eds.), The Community College Baccaluareate: Emerging Trends and Policy Issues (pp. 49-72). Sterling, VA: Stylus Publishing. 